JMKSP (Jurnal Manajemen, Kepemimpinan, dan Supervisi Pendidikan)

Volume 7 Issue 1 (2022) Page 389-398

ISSN 2614-8021 (Online) 2548-7094 (Print)

\title{
Implementation of Light Rapid Transit Transport Infrastructure Development Policy on the Development of Mass Transport in Palembang
}

\author{
Sri Kartini ${ }^{1}$, Yeti Komalasari ${ }^{2}$, Monica Amanda ${ }^{1}$ \\ ${ }^{1}$ Politeknik Transportasi SDP Palembang, ${ }^{2}$ Politeknik Penerbangan Palembang \\ Corresponding Author E-mail: crie_llsdp171@yahoo.com
}

Received 13 December 2021; Revised 30 January 2022; Accepted 25 March 2022

Abstract: The purpose of this study is to describe and analyze the implementation of policies for the development of Light Rapid Transit (LRT) transportation infrastructure in Palembang City and analyze the factors that hinder the development of Light Rapid Transit (LRT) as mass transportation in Palembang City. The research method uses the constructivism paradigm through qualitative research approaches and types with data collection techniques through observation, interviews, and documentation. The main finding in this study is the implementation of light rail transportation infrastructure development policies towards the development of mass transportation in the city of Palembang within the scope of public service standards, there are 6 (six) scopes of public service standards that must be set at least covering the fulfillment of service procedures, completion time, cost services, service products, facilities and infrastructure as well as the competence of service providers, from 6 (six) factors there are 3 (three) factors of which have been fulfilled. The novelty/originality in this study is supported by the latest observational data and studies that support the improvement of the implementation of LRT development policies in realizing the role of mass transportation in Palembang.

Keywords: Public Policy, Light Rapid Transit, Mass Transport

\section{Introduction}

Public policy is a product of government, and that either the policy to do or not to do something has the same weight (Howlett and Ramesh, 1995). Ideally, a 
metropolitan city as big as Palembang has a mass transportation system (either road or rail-based) which is the backbone of urban passenger transport services. Therefore, the development of a mass transportation system is urgent enough to be realized in Palembang City.

Currently, the public transportation system in Palembang City has been served by 8 Trans Musi corridors, 7 conventional bus routes, 5 angkot routes and 5 taxi companies. However, the role of the road-based public transportation mode has not been able to overcome the increasingly evenly distributed congestion in the symbol city in the past few years. This prompted the emergence of proposals for the development of a light rail-based mass transportation system (monorail/LRT) in the city of Palembang. Public policy must be in accordance with and adapt to the demands and challenges of the times, and at the same time become a 'tool for the welfare and fulfillment of community needs' (Putra, 2003).

Understanding of public policy is divided into two categories. First, expert opinion equates public policy with government actions (Ali and Alam, 2012). Experts in this group tend to assume that all government actions can be referred to as public policy (Hawlet and Ramesh, 1995; Nugroho, 2009). The second view is that experts pay special attention to policy implementation. Experts who fall into this category are divided into two camps, namely those who view public policies as government decisions (Santoso, 1993; Winarno, 2012).

There are 3 (three) factors that influence the implementation of a policy, namely the policy formulation, implementing personnel, and implementing organizations (Rohman, 2009). Every public service provider must have service standards and be published as a guarantee of certainty for service recipients, the scope of public services is determined to at least include service procedures, completion times, service costs, service products, infrastructure facilities and the competence of service providers (Mahmudi, 2009; Purwanto and Sulistyastuti, 2012).

\section{Methods}

This research is a qualitative type of research as a research procedure that produces descriptive data in the form of written or spoken words from people and observable behavior (Bogdan and Taylor, 1993). Researchers used several data collection techniques, namely observation, interviews and documentation. The research location is in the Ministry of Transportation of the Republic of Indonesia, especially in the South Sumatra Light Rail Management Center as the light rail 
operator and PT Kereta Api Indonesia (Persero) as the light rail operator. The research instrument is the researcher himself (the author) who is directly involved in the research (Bungin, 2008; Moleong, 2000).

Sources of information for qualitative research are informants or resource persons related to research problems and by researchers are considered capable of providing information and data (Sugiyono, 2007). Informant I: Section Head of Facilities and Infrastructure Utilization; Informant II: Public Service Agency Commitment Making Officer; Informant III: Management of Number of Passengers and Revenue; and Informant IV: Train Travel Organizer.

\section{Results and Discussion}

The measurement of the Community Satisfaction Index (IKM) is carried out with a community satisfaction survey which is a comprehensive measurement activity of the level of community satisfaction with the quality of services provided by public service providers. In 2020, SMIs with the "GOOD" category were obtained for 12 service elements that became the basis for taking the survey, including 1) South Sumatra LRT service both at the station and on the train; 2) Ticket purchase service; 3) Cleanliness of toilets and places of worship at the station; 4) The ability of officers to provide services; 5) Travel time and waiting time; 6) Quality of South Sumatra LRT facilities and infrastructure; 7) South Sumatra LRT ticket prices; 8) Integrated transportation services; 9) Facilities for getting on/off the South Sumatra LRT passengers; 10) Safety at the station and above the LRT South Sumatra; 11) Facilities for passengers belonging to vulnerable groups; 12) Handling of complaints from South Sumatra LRT service users.

Tabel 1. Community Satisfaction Index in 2021

\begin{tabular}{|l|l|l|l|l|c|c|}
\hline \multirow{2}{*}{ NO. } & \multirow{2}{*}{ ELEMEN OF SERVICE } & \multicolumn{6}{|c|}{$\mathbf{2 0 2 0}$} & \multirow{2}{*}{ TW } \\
\cline { 3 - 5 } & & $\begin{array}{l}\text { TW } \\
\text { II }\end{array}$ & $\begin{array}{l}\text { TW } \\
\text { III }\end{array}$ & $\begin{array}{c}\text { TW } \\
\text { IV }\end{array}$ & AVERAGE \\
\hline U1 & $\begin{array}{l}\text { What is your opinion about the South } \\
\text { Sumatra LRT service? }\end{array}$ & 3,39 & 3,47 & 3,38 & 3,30 & $\mathbf{3 , 3 9}$ \\
\hline U2 & $\begin{array}{l}\text { What is your understanding of buying } \\
\text { tickets? }\end{array}$ & 3,53 & 3,57 & 3,46 & 3,40 & $\mathbf{3 , 4 9}$ \\
\hline U3 & $\begin{array}{l}\text { What do you think about the } \\
\text { cleanliness of the toilets and places of } \\
\text { worship at the South Sumatra LRT }\end{array}$ & 3,36 & 3,40 & 3,27 & 3,30 & $\mathbf{3 , 3 3}$ \\
\hline
\end{tabular}




\begin{tabular}{|c|c|c|c|c|c|c|}
\hline \multirow[b]{2}{*}{ NO. } & \multirow[b]{2}{*}{ ELEMEN OF SERVICE } & \multicolumn{4}{|c|}{2020} & \multirow[b]{2}{*}{ AVERAGE } \\
\hline & & $\begin{array}{l}\text { TW } \\
\text { I }\end{array}$ & $\begin{array}{l}\text { TW } \\
\text { II }\end{array}$ & $\begin{array}{l}\text { TW } \\
\text { III }\end{array}$ & $\begin{array}{l}\text { TW } \\
\text { IV }\end{array}$ & \\
\hline & Station? & & & & & \\
\hline $\mathrm{U} 4$ & $\begin{array}{l}\text { What do you think about the ability } \\
\text { of officers to provide services? }\end{array}$ & 3,36 & 3,35 & 3,30 & 3,30 & 3,33 \\
\hline U5 & What do you think about & 3,09 & 2,90 & 2,83 & 3,10 & 2,98 \\
\hline U6 & $\begin{array}{l}\text { What do you think about the quality of } \\
\text { South Sumatra LRT facilities and } \\
\text { infrastructure? }\end{array}$ & 3,25 & 3,21 & 3,26 & 3,30 & 3,25 \\
\hline U7 & $\begin{array}{l}\text { What do you think about the South } \\
\text { Sumatra LRT ticket prices? }\end{array}$ & 3,33 & 3,46 & 3,42 & 3,40 & 3,40 \\
\hline U8 & $\begin{array}{l}\text { What do you think about the existing } \\
\text { integrated transportation service? }\end{array}$ & 3,14 & 3,04 & 3,01 & 3,20 & 3,10 \\
\hline U9 & $\begin{array}{l}\text { What do you think about the } \\
\text { boarding/alighting facilities at the } \\
\text { station and passenger platform? }\end{array}$ & 3,33 & 3,34 & 3,28 & 3,30 & 3,31 \\
\hline U10 & $\begin{array}{l}\text { What do you think about security at } \\
\text { the station and on the train? }\end{array}$ & 3,41 & 3,47 & 3,35 & 3,40 & 3,41 \\
\hline U11 & $\begin{array}{l}\text { What do you think about the existing } \\
\text { facilities for passengers with special } \\
\text { needs? }\end{array}$ & 3,29 & 3,37 & 3,28 & 3,30 & 3,31 \\
\hline U12 & $\begin{array}{l}\text { What do you think about the handling } \\
\text { of complaints from service users on } \\
\text { the South Sumatra LRT? }\end{array}$ & 3,57 & 3,52 & 3,53 & 3,60 & 3,56 \\
\hline \multicolumn{2}{|c|}{ AVERAGE SATISFACTION INDEX } & 3,34 & 3,34 & 3,28 & 3,33 & 3,32 \\
\hline
\end{tabular}

Source: South Sumatra Light Railway Management Center, 2021

From the 12 elements that need improvement are waiting time and travel time and integrated transportation services, while based on the average survey results in the first, second and third quarters, the average IKM result is 3.3 with the "GOOD" category."

Theoretical discussion is one way to discuss the implementation of the Light Rapid Transit (LRT) transportation infrastructure development policy on the development of mass transportation in the city of Palembang which was conducted by interviewing experts/stakeholders, namely the South Sumatra Light Rail Management Center and PT. Kereta Api Indonesia (Persero) Divre III (Nugroho and Dahuri, (2012). The selection of resource persons is based on their field of duty and also has approximately 5 years of experience with the scope of 
public service standards which include service procedures, completion times, service costs, service products, facilities and infrastructure as well as the competence of service providers. see the results in the following table.

\section{Table 2. Interview Results Coverage of Public Service Standards}

\begin{tabular}{|c|c|c|c|c|c|}
\hline \multirow{2}{*}{ No } & \multirow{2}{*}{$\begin{array}{c}\text { Scope of Public } \\
\text { Service } \\
\text { Standards }\end{array}$} & \multicolumn{4}{|c|}{ Respondents / Informants } \\
\hline & & I & II & III & IV \\
\hline 1 & $\begin{array}{l}\text { Service } \\
\text { Procedure }\end{array}$ & $\begin{array}{l}\text { Minister of } \\
\text { Transportation } \\
\text { Regulation } \\
\text { Number } 69 \text { of } \\
2019 \\
\text { concerning } \\
\text { Minimum } \\
\text { Service } \\
\text { Standards for } \\
\text { Transporting } \\
\text { People by } \\
\text { Train while } \\
\text { derivatives in } \\
\text { the form of } \\
\text { SOPs are being } \\
\text { set by the } \\
\text { South Sumatra } \\
\text { Light Rail } \\
\text { Management } \\
\text { Center }\end{array}$ & $\begin{array}{l}\text { The SOP is in } \\
\text { the process of } \\
\text { being reviewed } \\
\text { by the South } \\
\text { Sumatra Light } \\
\text { Railroad } \\
\text { Management } \\
\text { Center which is } \\
\text { currently in } \\
\text { general use and } \\
\text { this year's } \\
\text { target can be } \\
\text { completed, } \\
\text { while in terms } \\
\text { of service user } \\
\text { satisfaction, it } \\
\text { is based on the } \\
\text { Community } \\
\text { Satisfaction } \\
\text { Index (IKM) } \\
\text { survey. }\end{array}$ & $\begin{array}{l}\text { Regulation } \\
\text { of the } \\
\text { Minister of } \\
\text { Transportati } \\
\text { on Number } \\
69 \text { of } 2019 \\
\text { concerning } \\
\text { Minimum } \\
\text { Service } \\
\text { Standards } \\
\text { for } \\
\text { Transportati } \\
\text { on of People } \\
\text { by Train }\end{array}$ & $\begin{array}{l}\text { Minister of } \\
\text { Transportation } \\
\text { Regulation Number } \\
69 \text { of } 2019 \\
\text { concerning } \\
\text { Minimum Service } \\
\text { Standards for } \\
\text { Transport of People } \\
\text { by Train and SOPs } \\
\text { issued in } \\
\text { accordance with } \\
\text { the Regulation of } \\
\text { the Head of } \\
\text { Regional Division } \\
\text { III Palembang } \\
\text { Number } \\
\text { SOP.EVP.DV.III/K } \\
\text { L.104/II/3/DV.3- } \\
\text { 2021 issued on } 26 \\
\text { february 2021 }\end{array}$ \\
\hline 2 & $\begin{array}{l}\text { Completion } \\
\text { Time }\end{array}$ & $\begin{array}{l}\text { There is no } \\
\text { hotline yet, } \\
\text { only an IKM } \\
\text { survey is } \\
\text { carried out }\end{array}$ & $\begin{array}{l}\text { The hotline in } \\
\text { planning is } \\
\text { currently using } \\
\text { a monthly IKM } \\
\text { survey }\end{array}$ & $\begin{array}{l}\text { IKM survey } \\
\text { in } 202098 \% \\
\text { of } \\
\text { complaints } \\
\text { completed } \\
2 \% \text { in the } \\
\text { process of } \\
\text { completion }\end{array}$ & $\begin{array}{l}\text { There has been a } \\
\text { follow-up SOP for } \\
\text { complaints in } \\
\text { accordance with } \\
\text { the Regulation of } \\
\text { the Head of } \\
\text { Regional Division } \\
\text { III Palembang } \\
\text { Number } \\
\text { SOP.EVP.DV.III/K } \\
\text { L.104 /II/3 /DV.3- } \\
2021 \text { issued on } 26 \\
\text { February } 2021\end{array}$ \\
\hline 3 & Service Fee & In accordance & There are & Minister of & The tariff setting \\
\hline
\end{tabular}




\begin{tabular}{|c|c|c|c|c|c|}
\hline & & $\begin{array}{l}\text { with the } \\
\text { Regulation of } \\
\text { the Minister of } \\
\text { Transportation } \\
\text { Number } 22 \text { of } \\
2020 \\
\text { concerning } \\
\text { LRT tariffs and } \\
\text { the } \\
\text { determination } \\
\text { of tariff details } \\
\text { are contained } \\
\text { in the } \\
\text { Regulation of } \\
\text { the Minister of } \\
\text { Transportation } \\
\text { Number } 197 \text { of } \\
2015 \text { for the } \\
\text { pioneering } \\
\text { tariff } \\
\text { component } \\
\text { which has been } \\
\text { running for } 4 \\
\text { years. }\end{array}$ & $\begin{array}{l}\text { subsidies from } \\
\text { the central and } \\
\text { local } \\
\text { governments } \\
\text { because they } \\
\text { are still } \\
\text { pioneers }\end{array}$ & $\begin{array}{l}\text { Transportati } \\
\text { on } \\
\text { Regulation } \\
\text { No. } 22 \text { of } \\
2020 \\
\text { regarding } \\
\text { LRT tariffs } \\
\text { and the } \\
\text { determinatio } \\
\text { n of tariff } \\
\text { details are } \\
\text { contained in } \\
\text { Minister of } \\
\text { Transportati } \\
\text { on } \\
\text { Regulation } \\
\text { No. } 197 \text { of } \\
2015 \text { for } \\
\text { pioneering } \\
\text { tariff } \\
\text { components }\end{array}$ & $\begin{array}{l}\text { authority is } \\
\text { managed by the } \\
\text { South Sumatra } \\
\text { Light Railroad } \\
\text { Center with the } \\
\text { current fare to the } \\
\text { airport of Rp. } \\
10,000 \text { for } \\
\text { destinations within } \\
\text { the city Rp. IDR } \\
5000 \text { and additional } \\
\text { integration IDR } \\
2000\end{array}$ \\
\hline 4 & $\begin{array}{l}\text { Service } \\
\text { Products }\end{array}$ & $\begin{array}{l}\text { Passenger } \\
\text { services } \\
\text { connecting the } \\
\text { airport to } \\
\text { DJKA and vice } \\
\text { versa with a } \\
17-19 \text { minute } \\
\text { headway still } \\
\text { meet the } \\
\text { standards set } \\
\text { by the world } \\
\text { bank for } \\
\text { measuring } \\
\text { service } \\
\text { performance }\end{array}$ & $\begin{array}{l}\text { Only for } \\
\text { passengers with } \\
\text { operating hours } \\
\text { starting from } \\
06.54-1954 \\
\text { with a total of } \\
88 \text { trips per } \\
\text { day, 17-19 } \\
\text { minutes } \\
\text { headway and } \\
47 \text { minutes } \\
\text { travel time to } \\
\text { DJKA and } 49 \\
\text { minutes to the } \\
\text { airport }\end{array}$ & $\begin{array}{l}\text { In-city } \\
\text { passenger } \\
\text { and cargo } \\
\text { services up } \\
\text { to } 20 \mathrm{~kg}\end{array}$ & $\begin{array}{l}\text { The service is } \\
\text { carried out only for } \\
\text { passengers and } \\
\text { goods with } \\
\text { dimensions of } \\
100 \times 40 \times 30 \mathrm{~cm} \\
\text { with a maximum } \\
\text { weight of } 20 \mathrm{~kg}\end{array}$ \\
\hline 5 & $\begin{array}{l}\text { Facilities and } \\
\text { infrastructure }\end{array}$ & $\begin{array}{l}\text { Adequate } \\
\text { infrastructure } \\
\text { and integrated } \\
\text { with other } \\
\text { modes of }\end{array}$ & $\begin{array}{l}\text { The } \\
\text { infrastructure } \\
\text { belonging to } \\
\text { the South } \\
\text { Sumatra Light }\end{array}$ & $\begin{array}{l}\text { Adequate } \\
\text { infrastructur } \\
\text { e both in } \\
\text { terms of } \\
\text { integration }\end{array}$ & $\begin{array}{l}\text { Provision of } \\
\text { facilities by PT. } \\
\text { KAI Facilities are } \\
\text { equipped for } \\
\text { vulnerable groups }\end{array}$ \\
\hline
\end{tabular}




\begin{tabular}{|l|l|l|l|l|l|}
\hline & & $\begin{array}{l}\text { transportation } \\
\text { and friendly to } \\
\text { vulnerable } \\
\text { groups }\end{array}$ & $\begin{array}{l}\text { Railroad Center } \\
\text { is integrated } \\
\text { and friendly to } \\
\text { vulnerable } \\
\text { groups }\end{array}$ & $\begin{array}{l}\text { and } \\
\text { vulnerable } \\
\text { groups }\end{array}$ & $\begin{array}{l}\text { (handicapped, } \\
\text { elderly, pregnant } \\
\text { women, and } \\
\text { toddlers) }\end{array}$ \\
\hline 6 & $\begin{array}{l}\text { Competence of } \\
\text { Service }\end{array}$ & $\begin{array}{l}\text { Service } \\
\text { providers are } \\
\text { provided by } \\
\text { PT. KAI and } \\
\text { its subsidiaries }\end{array}$ & $\begin{array}{l}\text { All service } \\
\text { providers are } \\
\text { certified } \\
\text { provided by } \\
\text { PT. KAI }\end{array}$ & $\begin{array}{l}\text { Provided by } \\
\text { PT. KAI and } \\
\text { has been } \\
\text { certified } \\
\text { according to } \\
\text { competence } \\
\text { in its field }\end{array}$ & $\begin{array}{l}\text { The existence of a } \\
\text { Service Level } \\
\text { Agreement (SLA) } \\
\text { and has a } \\
\text { certification and } \\
\text { every employee has } \\
\text { been certified and } \\
\text { the implementation } \\
\text { of service ethics by } \\
\text { providing sanctions } \\
\text { and rewards }\end{array}$ \\
\hline
\end{tabular}

From table 2, the results of interviews with the four experts/stakeholders, in general, it can be seen that the current operation of the South Sumatra LRT still needs to be improved for development as mass transportation as follows 1) The service procedure has been guided by the Ministerial Regulation so that the South Sumatra LRT Hall as the regulator has planned to make standard operating procedures involving several stakeholders in the railway sector, especially light trains targeted for completion in October 2021, while at PT. KAI already has a SOP (Standard Operating Procedure) issued in accordance with the Regulation of the Head of Regional Division III Palembang including: Standard Operating Procedures for Services at LRT Stations Number SOP.EVP.DV.III/KL.104 /II/3 /DV.3-2021 issued on 26 February 2021, and South Sumatra LRT (Light Rail Transit) payment system service number 300/CP/VIII/2018;

2) At the time of settlement, there is no special contact for handling complaints and also standard operating procedures in handling complaints, currently only by conducting a survey of the consumer satisfaction index (IKM) conducted by the South Sumatra LRT Management Center, which will then be resolved from the results of the IKM. In 2020, 43 complaints were recorded and $98 \%$ of complaints were followed up, the remaining $2 \%$ are still in the process of being resolved; 3 ) The cost of services is currently still subsidized with reference to the Minister of Transportation Regulation Number 197 of 2015 concerning cost components that can be calculated in the implementation of pioneer rail transportation and has been stipulated through the Minister of Transportation 
Regulation number 22 of 2020 concerning the tariff for transportation of people by pioneer train for the South Sumatra LRT. with airport service crossing to DJKA Rp. 10,000, Hajj Dormitory-DJKA RP. 5000 and an integration fee of Rp. $2000 ; 4)$ The product of the South Sumatra light rail service (LRT Sumsel) is the transportation of passenger services within the city and also passenger luggage with dimensions of 100x40x30 with a minimum weight of $20 \mathrm{~kg}$. Service during the COVID-19 pandemic is a maximum of 26\%, namely 115 passengers, consisting of 64 people sitting and 51 standing passengers. The number of South Sumatra LRT passengers from 2018 to August 2021 is 5,524,534;

5) The facilities and infrastructure for the South Sumatra light rail (LRT Sumsel) for the fulfillment of infrastructure are managed by the South Sumatra Light Rail Management Center while the facilities are provided by PT KAI (Persero) Divre III Palembang according to the minimum service standards regulated in the Minister of Transportation Regulation number 63 of 2019; and 6) Competence of service providers in terms of services for PT Kereta Api Indonesia (Persero) as a service provider for both stations and light rail. The South Sumatra LRT service officer has been certified and signed the Service Level Agreement, which is a contract or agreement between the company and the service provider (Kodoatie, 2005).

\section{Conclusion}

There are 6 (six) scopes of public service standards that must be set at least covering the fulfillment of service procedures, completion time, service costs, service products, facilities and infrastructure as well as the competence of factor service providers. There are 3 (three) factors of which have been fulfilled 1) The service fee has been determined through the Minister of Transportation Regulation number 22 of 2020 regarding the tariff for transporting people by pioneer train for the South Sumatra LRT with airport service crossings to DJKA for IDR 10,000, Hajj Dormitory-DJKA RP. 5000 and an integration fee of Rp. 2000 ; 2) Service products, namely the transportation of passenger services within the city and also passenger luggage with dimensions of $100 \times 40 \times 30$ with a minimum weight of $20 \mathrm{~kg}$. Travel time and waiting time are still in accordance with the criteria for public transport services; and 3) The competence of the officer has been certified and signed a Service Level Agreement (SLA), which is a contract or agreement between the company and the service provider that states in detail the expectations and obligations of the relationship. 


\section{Acknowledgment}

Thanks are given to all parties who have contributed to the completion of this study 1) Director of the Palembang SDP Transportation Polytechnic and his staff; 2) Director of the Palembang Aviation Polytechnic and his staff; 3) Head of the South Sumatra Light Rail Management Center and his staff; 4) Directors of PT Kereta Api Indonesia (Persero) and their staff; and 5) Informants/Sources in this study.

\section{References}

Ali, F, and Alam, S. A. (2012). Government Policy Studies. Bandung: Refika Aditama

Bungin, B. (2008). Qualitative Research Methodology: Methodological Actualization Towards Contemporary Variants. Jakarta: Raja Grafindo Persada

Bogdan., \& Taylor. (1993). Introduction to Qualitative Research Methods a Phenomenological Approach to the Social Science. Surabaya: National Effort

Hawlet, M., \& Ramesh, M. (1995). Studying Public Policy. Oxford University Press.

Kodoatie, R. J. (2005). Introduction to Infrastructure Management. Yogyakarta: Student Library

Mahmudi. (2009). Public Sector Performance Management. Jakarta

Moleong, L. J. (2000) Qualitative Research Methodology. Bandung: Remaja Rosdakarya

Nugroho, I., \& Dahuri, R. (2012). Regional Development: Economic, Social and Environmental Perspectives LP3ES. Jakarta 
Nugroho, R. D. (2009). Public Policy (Formulation, Implementation, and Evaluation). Jakarta: Gramedia

Purwanto, E. A., \& Sulistyastuti, D. R. (2012). Public Policy Implementation, Concepts and Applications in Indonesia. Yogyakarta: Gava Media

Putra, F. (2003). Political Parties and Public Policy. Yogyakarta: Pustaka Belajar Rohman, A. (2009). Understanding Education and Educational Science. Yogyakarta: Laksbang Mediatama

Santoso, A. (1993). Public Policy Analysis. Journal of Political Science, 3(1)

Sugiyono. (2007). Statistics for Research. Bandung: Alfabeta

Winarno, B. (2012). Public Policy, Process Theory, and Case Studies. Yogyakarta: CAPS 